\title{
Purification and characterizations of a novel recombinant Bacillus velezensis endoglucanase by aqueous two-phase system
}

Yang Liu ${ }^{1,2,3}$, Haipeng Guo ${ }^{1,4}$, Yanwen Wu ${ }^{1,5}$ and Wensheng Qin ${ }^{1 *}$

\begin{abstract}
Background: Cellulases played an important role in the production of bioenergy and bio-products. Cellulases from bacteria with some special characteristics drew great attention due to its fast growth speed, wide adaption to harsh environment, and production of multi-function cellulases.

Results: An endoglucanase gene egls from Bacillus velezensis A4 was cloned and expressed in Escherichia coli BL21 (DE3). The recombinant enzyme Egls was partially purified using aqueous two-phase system. The highest recovery rate of the enzyme was $90.39 \%$ at PEG 4000 (25\% w/w), phosphate buffer $8.08 \%(\mathrm{w} / \mathrm{w})(\mathrm{pH} 6.0)$, and $\mathrm{NaCl}(5 \% \mathrm{w} / \mathrm{w})$. The enzyme molecular weight was $55 \mathrm{KD}$ estimated by zymogram. The optimal $\mathrm{pH}$ and temperature of recombinant enzyme Egls were $\mathrm{pH} 6.0$ and $55^{\circ} \mathrm{C}$, respectively. The enzyme was stable at $\mathrm{pH}$ range of $5.0-7.0$ at $55^{\circ} \mathrm{C}$ for $60 \mathrm{~min}$. The enzyme exhibited $K_{\mathrm{m}}, V_{\mathrm{max}}, K_{\text {cat }}$ values as $63.38 \mathrm{mg} / \mathrm{ml}, 55.6 \mathrm{mg} / \mathrm{min}$, and $3.93 \times 10^{3} / \mathrm{S}$, respectively. The addition of $10 \mathrm{mM}$ of $\mathrm{Mg}^{2+}, \mathrm{Mn}^{2+}$, or $5 \%$ (w/w) of Triton-X 100 in the reaction system enhanced the enzyme activity significantly. The enzyme showed both endoglucanase and exoglucanase activity.

Conclusions: An endoglucanase gene egls from B. velezensis A4 was cloned and expressed in E. coli BL21 (DE3). The recombinant enzyme Egls was purified by aqueous two-phase system and characterized. The enzyme can be applied for the efficient pretreatment of lignocellulosic biomass for bioenergy and bio-products production.
\end{abstract}

Keywords: Purification and characterizations, Endoglucanase, Bacillus velezensis, Aqueous two-phase system

\section{Background}

Cellulose, hemicellulose, and lignin are the most abundant, cheap, and renewable nature resources in the world (Basu 2013). Cellulose accounts for about $1 / 3$ of the lignocellulosic biomass (Sun and Cheng 2002). Hydrolysis of cellulose to produce reducing sugars using lignocellulosic biomass is extremely important in the production of renewable bioenergy and other bio-products (Pérez et al. 2002; Yang et al. 2014).

The biodegradation of cellulose was mainly conducted by various kinds of cellulase (Endoglucanase, exoglucanase, and $\beta$-glucosidase) (Garvey et al. 2013). Endoglucanases randomly cut the cellulose polysaccharide

\footnotetext{
*Correspondence: wqin@Lakeheadu.ca

1 Department of Biology, Lakehead University, Thunder Bay, ON P7B 5E1, Canada

Full list of author information is available at the end of the article
}

chain, generating various lengths of oligosaccharides. Exoglucanases act on the ends of cellulose polysaccharide chains, producing either glucose or cellobiose as major products. $\beta$-glucosidases hydrolyze cellobiose from nonreducing end to produce glucose (Rabinovich et al. 2002).

Cellulases could be produced by various fungi and bacteria. Fungi have the ability to produce abundant amounts of cellulolytic enzymes and are mainly exploited to produce cellulases (Sharada et al. 2013). However, cellulases from bacteria have been paid more attention because it has fast growth speed, wide adaption to extreme environment, and can produce more complex and muti-function cellulases to meet the industrial needs (Sadhu and Maiti 2013). Although numerous cellulases from different bacteria species have been studied and characterized (Rabinovich et al. 2002; Sadhu and Maiti 2013; Sharada et al. 
2013), the cellulases with novel properties are still needed to be further explored for bioenergy production.

Aqueous two-phase systems (ATPS) are formed by mixing certain amounts of polymers, salts, and water together, which have been extensively used to separate and purify nuclear acids, cells and organelles, enzymes, and proteins (Asenjo and Andrews 2011; Raja et al. 2012). ATPS have many advantages such as low toxic to environment, continuous to operate, and easy to scale up (Hatti-kaul 2001). It is one of low cost and high-efficient purification methods (Asenjo and Andrews 2011). Recently, many enzymes ( $\alpha$-amylase, $\alpha$-galactosidase, lipase, proteinase), recombinant proteins, and antibody have been purified using this method (Azevedo et al. 2009; Porfiri et al. 2011; Gu et al. 2012; Loc et al. 2013; Ramakrishnan et al. 2016).

Bacillus velezensis A4 was isolated from forest soil previously in our lab, which exhibited strong ability in hydrolysis of lignocellulosic biomass (Guo et al. 2017). In order to further investigate the lignocellulosic enzyme properties from the A4 strain, the endoglucanase encoding gene was cloned and expressed in Escherichia coli. The enzyme was purified with ATPS and enzyme properties were characterized.

\section{Methods}

\section{Bacterial strain and cultural condition}

The Bacillus sp. A4 strain was used in this study which was isolated from the forest soil (Guo et al. 2017). The strain was activated by streaking in Luria-Bertani (LB) plate incubating at $37{ }^{\circ} \mathrm{C}$ overnight. Then a single colony was inoculated to $20 \mathrm{ml}$ of liquid medium and cultured overnight in a shaker at $37{ }^{\circ} \mathrm{C}$ with $200 \mathrm{rpm}$. One percent $(\mathrm{v} / \mathrm{v})$ of the cultural broth was transferred into $50 \mathrm{ml}$ mineral salt medium (MSM) containing $0.05 \%(w / v)$ carboxymethylcellulose sodium (CMC) and cultured in a shaker at $37^{\circ} \mathrm{C}$ with $200 \mathrm{rpm}$ for $80 \mathrm{~h}$. The MSM medium consisted of (g/l) $\mathrm{KH}_{2} \mathrm{PO}_{4} 1.0 \mathrm{~g}, \mathrm{KCl} 1.0 \mathrm{~g}, \mathrm{NaNO}_{3} 1.0 \mathrm{~g}$, $\mathrm{MnSO}_{4} 0.5 \mathrm{~g}$, yeast extract $0.5 \mathrm{~g}$, peptone $3 \mathrm{~g}, \mathrm{pH}$ 7.0. The cultural medium was sterilized at $121^{\circ} \mathrm{C}$ for $20 \mathrm{~min}$ before use.

\section{rpoB gene amplification and strain identification}

The genome DNA was extracted using the method (Aljanabi 1997). The $r p o B$ gene fragment was amplified with the primers CM7: 5'-AACCAGTTCCGCGTTGGCCTGG-3 (1383 bp) and CM31b: 5'-CCTGAACAACACGCTCGGA-3 (2473 bp) (Mollet et al. 1997). The PCR-amplified fragment was purified with DNA purification kit (Thermo Fisher Scientific, Canada) and sent for sequencing. The rpoB gene sequence of the strain was blasted with GenBank (https://blast.ncbi.nlm. nih.gov/Blast.cgi). The highly similar $r p o B$ gene sequence from different Bacillus strains was retrieved from GenBank and aligned using software Clustal X 1.83. The phylogenetic tree was constructed with software MEGA 7.01 using the neighbor-joining method.

\section{Egls gene cloning and sequence analysis}

The endoglucanase gene (egls) fragment was amplified with the forward primer (5'-GGATCCATGCGAAGGAGGAAAAGATCAGAT) and reverse primer (5'-AAGCTTATTKGGTTCYGTTCCCCAAATCAGT). The restriction sites BamHI and HindIII were shown underline. The PCR product was purified with a DNA purification kit (Thermo Fisher Scientific, Canada). The fragment was ligated to the vector PJET1.2-T and transformed into E. coli JM109. The plasmid was extracted and digested with enzymes BamHI and HandIII. The egls fragment was purified with Gel Extraction kit and ligated with the vector pET-21a in the corresponding sites. The degenerated plasmid was named pET21-egls, which has a 6 His-tag at the C-terminus of egls gene. The plasmid was sent to sequence and analyze.

The Nucleotide and amino acid sequences were analyzed with the online software BLASTn and BLASTp (http://blast.ncbi.nlm.nih.gov/Blast.cgi). The conserved domains were predicted using bioinformatics tools (http://www.ncbi.nig.gov/structure/cdd/wrpsb.cgi). The signal peptide of Egls was predicted using online program Signal P 4.2 (http://www.cbs.dtu.dk/services/SignalP/). The molecular weight (MW) and theoretical isoelectric point (PI) were analyzed using the software Vector NTI Advance 11.5.1. Multiple sequence alignment analysis was performed using software CLUSTAL $\times 1.8$. Homology model was built using the online software (https:// swissmodel.expasy.org/).

\section{Recombinant protein expression}

The recombinant strain E. coli DE3 harboring the plasmid pET21-egls was inoculated into LB broth supplemented with ampicillin $50 \mathrm{mg} / \mathrm{l}$. The strain was grown at $37{ }^{\circ} \mathrm{C}$ with shaking at $200 \mathrm{rpm}$ overnight, and then it was inoculated to the same medium and was grown to OD600 0.5-0.6. After that, the recombinant strain was induced with $1 \mathrm{mM}$ IPTG at $20^{\circ} \mathrm{C}$ for $20 \mathrm{~h}$. The cell pellets were collected in $50-\mathrm{ml}$ conical tubes by centrifuging at room temperature for $10 \mathrm{~min}$ at $5000 \mathrm{rpm}$. The enzyme was purified with HisPur ${ }^{\mathrm{TM}} \mathrm{Ni}-\mathrm{NTA}$ Spin Purification Kit (Thermo fisher, Canada) under the native conditions. The recombinant protein was eluted with $500 \mathrm{mM}$ imidazole in phosphate buffer ( $\mathrm{pH}$ 8.0) and desalted with PD-10 column (Thermo fisher, Canada). The protein concentration was assayed according to the instruction of Bradford Protein Assay Kit (Bio Basic Canada Inc., Markham, Canada). SDS-PAGE was performed with $5 \%(\mathrm{w} / \mathrm{v})$ stacking 
gel and 12\% (w/v) separating gel, respectively, under denature conditions. Zymogram analysis was carried out using the method (Lin et al. 2015).

\section{Enzyme activity assay}

Endoglucanase activity was assayed according to the method (Ghose 1987) with minor modification using $\mathrm{CMC}$ as substrate. The reaction was carried out by adding $50 \mu \mathrm{l}$ enzyme extraction into $50 \mu \mathrm{l}$ of $0.05 \%(\mathrm{w} / \mathrm{v})$ CMC substrate in $50 \mathrm{mM}$ citrate buffer $(\mathrm{pH} 4.8)$ and incubated at $55^{\circ} \mathrm{C}$ for $30 \mathrm{~min}$. The released reducing sugars were measured by DNS method (Miller 1959), using glucose as standard curve. One unit of enzyme activity was defined as the amount of enzyme which could release $1 \mu \mathrm{g}$ of reducing sugar in $1 \mathrm{~min}$ under assay conditions.

Exoglucanase activity and filter paper activity (FPA) assay was carried out in the same conditions as endoglucanase determination using $1 \%(\mathrm{w} / \mathrm{v})$ Avicel and Whiteman No. 1 filter paper $(0.3 \times 0.5 \mathrm{~cm})$ as substrate, respectively. The released reducing sugars from Avicel were determined by phenol-sulfuric acid method (Masuko et al. 2005), using glucose as standard curve. One unit of enzyme activity was defined as the amount of enzyme which could release $1 \mu \mathrm{g}$ of reducing sugars in 1 min under assay conditions.

The $\beta$-glucosidase activity was assayed according to the method (Zhang et al. 2009), with minor modifications using pNPG as substrate. Briefly, $10 \mu \mathrm{l}$ of enzyme was added into $140 \mu \mathrm{l}$ of $1 \mathrm{mM}$ pNPG substrate in $50 \mathrm{mM}$ sodium citrate buffer ( $\mathrm{pH} 4.8)$ and incubated at $55{ }^{\circ} \mathrm{C}$ for $30 \mathrm{~min}$. Then $200 \mu \mathrm{l}$ of $0.4 \mathrm{M}$ glycine buffer ( $\mathrm{pH}$ 10.8) was added into the reaction mixture. The appearance of yellow color was monitored at $430 \mathrm{~nm}$ by Microplate Spectrophotometer (Epoch, Bio Tek Instruments, Inc., Winooski, VT, USA). One unit of enzyme activity was defined as the enzyme released $1 \mathrm{mM}$ of $p$-nitrophenyl per minute under assay conditions.

\section{Enzyme purification with ATPS Binodal curves preparation}

The bimodal curves were determined with turbidity method without $\mathrm{NaCl}$ (Asenjo and Andrews 2012). One g of $50 \%(\mathrm{w} / \mathrm{w})$ PEG solution was added into a $15-\mathrm{ml}$ tube. Then, the $40 \%(\mathrm{w} / \mathrm{w})$ of citrate solution was added drop by drop, until the mixture becomes cloudy. The weight of PEG 4000 solution, phosphate buffer ( $\mathrm{pH}$ 6.0), and the total weight of the tube were written down to calculate the ratio of PEG solution and citrate buffer solution in the system. After that some distilled water was added to make the system clear until one-phase system appeared. The above process was repeated 8-10 times until enough data were obtained to plot binodal curves.

\section{Enzyme purification with two-phase system}

Aqueous two-phase systems were prepared at room temperature by mixing certain amounts of $50 \%(w / w)$ of PEG solution, $40 \%(\mathrm{w} / \mathrm{w})$ of phosphate buffer, $2 \mathrm{ml}$ cell culture supernatant sonicated in $50 \mathrm{mM}$ of citrated buffer $(\mathrm{pH}$ 6.0), and $\mathrm{NaCl}$ in $15 \mathrm{ml}$ centrifuge tubes with conical cap. $\mathrm{pH}$ was pre-adjusted to (6.0-8.0) in phosphate buffer. Distilled water was added to the system to obtain $10 \mathrm{~g}$ of total weight. After vortex for $5 \mathrm{~min}$, the tube was centrifuged at $5000 \mathrm{rpm}$ for $3 \mathrm{~min}$ to make the phase separate. Different concentrations of PEG $4000(10-25 \% \mathrm{w} / \mathrm{w})$, phosphate buffer $(8-18 \% \mathrm{w} / \mathrm{w})$, buffer $\mathrm{pH}(6-8)$, and $\mathrm{NaCl}(0-15 \%, w / w)$ were used to study the partition of the recombinant enzyme in ATPS.

Partition coefficient $(K)$ is the ratio of protein partitioned in the top phase to that of in the bottom phase. Purification factor (PF) is defined as the ratio of specific activity of the phase enzyme participated to that of the crude enzyme. Enzyme recovery (ER) is defined as the ratio of the total enzyme recovered from the phase to the total enzyme activity in crude enzyme.

\section{Biochemical characterizations of Egls The optimal $\mathrm{pH}$ and temperature}

The optimal $\mathrm{pH}$ and temperature for endoglucanase activities were measured in different $\mathrm{pH}$ values $(3.0$ $10.0)$ and various temperatures $\left(30-75{ }^{\circ} \mathrm{C}\right)$, respectively, using $0.05 \%(\mathrm{w} / \mathrm{v})$ of CMC in citrate buffer ( $\mathrm{pH} 4.8)$ as substrates. Sodium acetate buffers $(50 \mathrm{mM})$ were used to maintain the $\mathrm{pH}$ range of 3.0-5.0, phosphate buffer $(50 \mathrm{mM}) 6.0-8.0$, and glycine- $\mathrm{NaOH}$ buffer $(50 \mathrm{mM})$ $9.0-10.0$, respectively. The enzyme activity compared to the highest activity in percentage (\%) in the reaction conditions was shown as relative activity.

\section{The thermal and $\mathrm{pH}$ stability}

In thermal and $\mathrm{pH}$ stability assay, the purified Egls $(50 \mu \mathrm{g} /$ $\mathrm{ml}$ ) was incubated at temperature range of $30-80{ }^{\circ} \mathrm{C}$ for $15-60 \mathrm{~min}$ in $50 \mathrm{mM}$ citrate buffer $(\mathrm{pH} 4.8)$ at $\mathrm{pH} 3.0-$ 10.0 for $5 \mathrm{~h}$ at room temperature. The remained enzyme activity was measured under standard conditions. The original enzyme activity was set as $100 \%$. The relative enzyme activity (\%) was defined as the remained enzyme activity compared with original enzyme activity.

\section{Effects of metal ions and chemicals on endoglucanase on enzyme activity}

Effects of metal ions and chemicals on Egls activities were determined using 2 and $10 \mathrm{mM}$ of different metal irons $\left(\mathrm{CaCl}_{2}, \mathrm{MnCl}_{2}, \mathrm{MgCl}_{2}, \mathrm{NiCl}_{2}, \mathrm{ZnCl}_{2}, \mathrm{CuCl}_{2}\right.$, and $\left.\mathrm{KCl}\right)$ in $50 \mathrm{mM}$ citrate buffer (pH 4.8) and chemicals (SDS, Triton-X 100, Tween-20, EDTA and PMSF), respectively. 
The enzyme activities were assayed under standard conditions. The enzyme activity without addition of metal ions was defined as $100 \%$ and used as a control. The results were shown as relative activity (\%).

\section{Kinetic parameters $K_{\mathrm{m}} / k_{\text {cat }}$ assay}

Kinetic parameters $K_{\mathrm{m}}, V_{\max }$, and $k_{\text {cat }}$ were determined according to the procedure (Allison 2001). Twenty-two $\mathrm{U} / \mathrm{ml}$ of enzyme was used to digest $1-10 \mathrm{mg} / \mathrm{ml}$ of CMC substrate under optimized conditions. The data were analyzed and the Lineweaver-Burk plot was made by the software Origin version 8.0.

\section{Substrate specificity assay}

Different substrates were used to evaluate the specificities of the purified enzyme Egls under the optimized conditions. The enzyme activity was measured under standard condition. The glucose was used as standard.

\section{Statistic analysis}

All the experiments were carried out in triplicate. The results were shown as mean \pm standard deviation. Oneway analysis of variance (ANOVA) was applied to analyze the significance of data. A $p<0.05$ was considered as statistically significant in data using Tukey's HSD method.

\section{Accession numbers}

The gene sequence of egls and rpoB were submitted to the GenBank with the Accession No (MG748603 and MG748604), respectively.

\section{Results and discussion}

\section{B. velezensis A4 growth and enzyme production}

The strain was inoculated at solid MSM medium with CMC $(0.05 \% \mathrm{w} / \mathrm{v})$ for $48 \mathrm{~h}$. A big halo in petri dish indicated that the bacteria could produce a large amount of cellulase to hydrolyze the substrate (Fig. 1a). The strain was grown in MSM medium at $37^{\circ} \mathrm{C}$ for $80 \mathrm{~h}$, and the cell growth and enzyme production were determined (Fig. 1b). The bacteria grew very quickly at first $8 \mathrm{~h}$ and the cell density reached the highest amount at $16 \mathrm{~h}$. The cell density almost remained constant over the times from 16 to $64 \mathrm{~h}$. The enzyme production began at $16 \mathrm{~h}$ and reached the highest amount $(21.71 \mathrm{U} / \mathrm{ml})$ at $48 \mathrm{~h}$.

\section{Strain identification}

This strain was identified as Bacillus sp. A4 previously by 16S rDNA (Guo et al. 2017), which showed $99 \%$ of identity with strain $B$. velezensis, Bacillus amyloliquefaciens, and Bacillus sp. These strains are very close in evolutionary relationship. The genus Bacillus is one of the most important enzyme production microorganisms, which consisted of 318 species (Dworkin et al 2006). Some Bacillus species such as $B$. velezensis, $B$. amyloliquefaciens, and Bacillus siamensis are highly closed in genetic relationship and it is hard to identify the species by $16 \mathrm{~S}$ rDNA methods (Fan et al. 2017). rpoB gene was found more useful to identify the strain within species than $16 \mathrm{~S}$ rDNA (Mollet et al. 1997). The rpoB gene is more sensitive in identifying the closest strains in evolutionary relationship, which has been used to identify the species

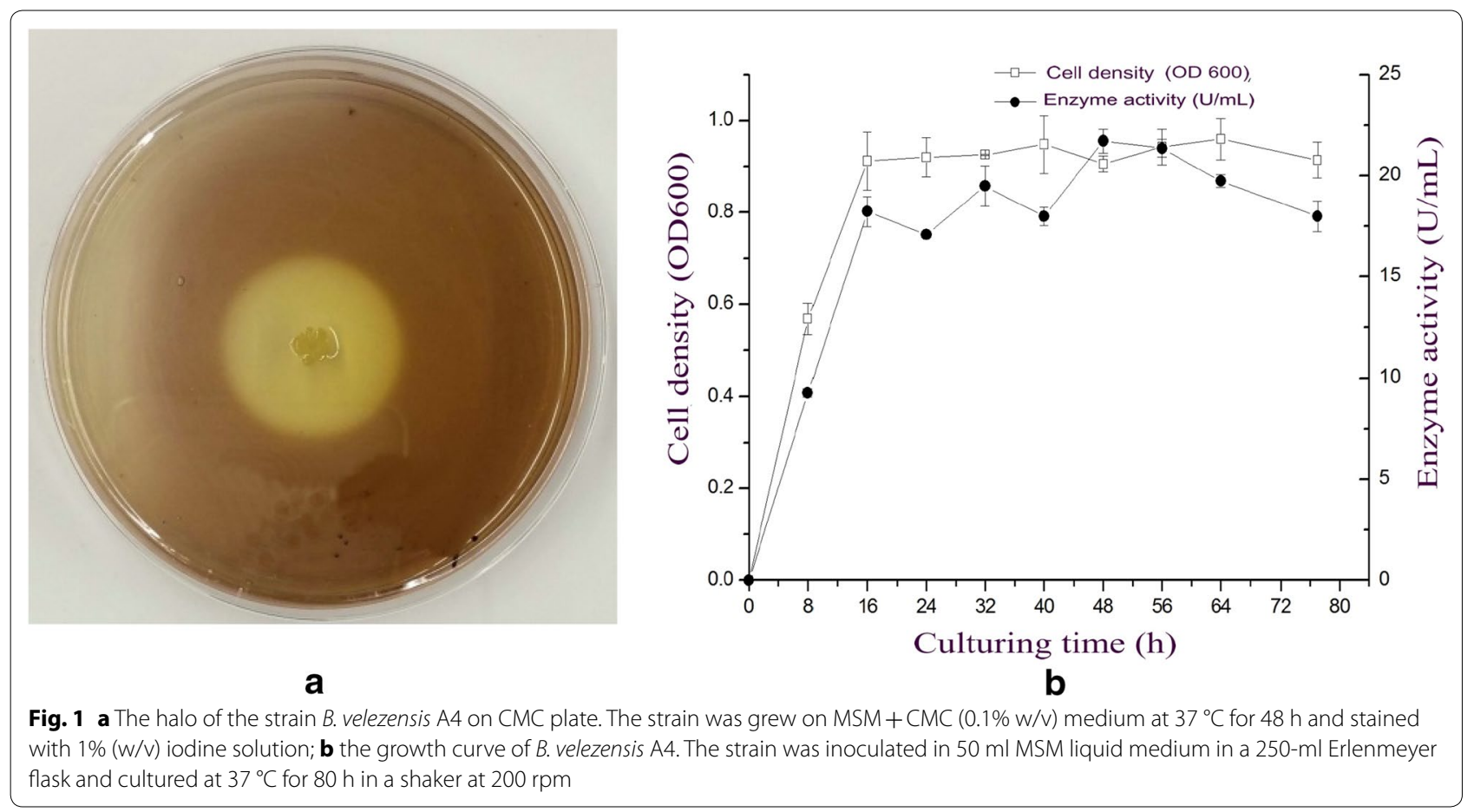


(Mollet et al. 1997; Drancourt and Raoult 2002; Ki et al. 2009). The rpoB gene of strain Bacillus sp. A4 was amplified with primers, sequenced, and homology blast performed with related species in GenBank. Results showed that the strain has $100 \%$ similarity with B. velezensis (Fig. 2). So we propose this strain belongs to $B$. velezensis. We named it $B$. velezensis A4.

\section{Egls gene sequence analysis}

The gene egls (GenBank Accession No. MG748603) has an open reading frame of $1521 \mathrm{bp}$, which encodes a protein of 507 amino acids with a calculated molecular weight $55.7 \mathrm{kD}$ and isoelectric point at 9.11. The enzyme protein has a signal peptide at $\mathrm{N}$-terminal (1-37 residues), predicted by Signal P 4.2 web software (Fig. 3).

The gene sequence egls showed $99 \%$ of sequence identity with the stain B. velezensis JS25R (GenBank Accession No. CP009679.1). Multiple amino acid BLAST analysis revealed that the enzyme Egls (residues 6-499) showed $100 \%$ sequence identity with glycoside hydrolase family 5 from B. velezensis (WP_022553273.1), but the first 5 amino acid is different (Fig. 4a).

Computer model of enzyme Egls shows that it consists of a $(\alpha / \beta)_{8}$ barrel, $7 \beta$ sheet strands, and a Manganese(II) binding site (Fig. $4 \mathrm{~b}$ ). The proposed conserved domains have cellulase domain (residues 50-296) (glycosyl hydrolase family 5), a CBM_3 cellulose-binding domain (residues 356-437), and one $\mathrm{Mg}^{2+}$ binding site, related with amino acids (G157, D195, D197, N198). The enzyme showed $96.73 \%$ sequence identity with endoglucanase.
Some strains of $B$. velezensis species have been sequenced and endoglucanases were annotated in GenBank by bioinformatics methods. However, the enzyme characterizations were not been clearly investigated.

\section{Expression and purification of the recombinant enzyme} To investigate the enzyme function of Egls, the encoding sequence of egls with signal peptide sequence from $B$. velezensis A4 was cloned and expressed in E. coli (Fig. 5a). The enzyme was expressed using pET-21a vector, which has a C-terminal His-tag. The recombinant enzyme was induced and expressed with different concentrations (0.2-1.0 $\mathrm{mM})$ of IPTG. The enzyme showed the highest CMCase activity $(28.06 \pm 1.04 \mathrm{U} / \mathrm{ml})$ and filter activity $(16.07 \pm 0.87 \mathrm{U} / \mathrm{ml})$ induced with $0.4 \mathrm{mM}$ of IPTG, but no activity was detected in the cell pellet and supernatant of the culture broth. The recombinant enzyme was purified to homogeneity using NTA affinity column (data not shown). The molecular mass of Egls is shown $55 \mathrm{kD}$ in zymogram (Fig. 5b). Similarly, the endoglucanase from Bacillus subtilis was expressed and purified with molecular weight of $55 \mathrm{kD}$ (Li et al. 2008). However, no enzyme activity was detected when purified with NTA affinity column. This may be because His-tags generally have some minor effect on the structure of the native enzyme (Carson et al. 2007). His-tags are known to mediate oligomerization via metal cation and can interact with some metal ions $\left(\mathrm{Ca}^{2+}, \mathrm{Mg}^{2+}\right)$, which may affect the enzyme activity.

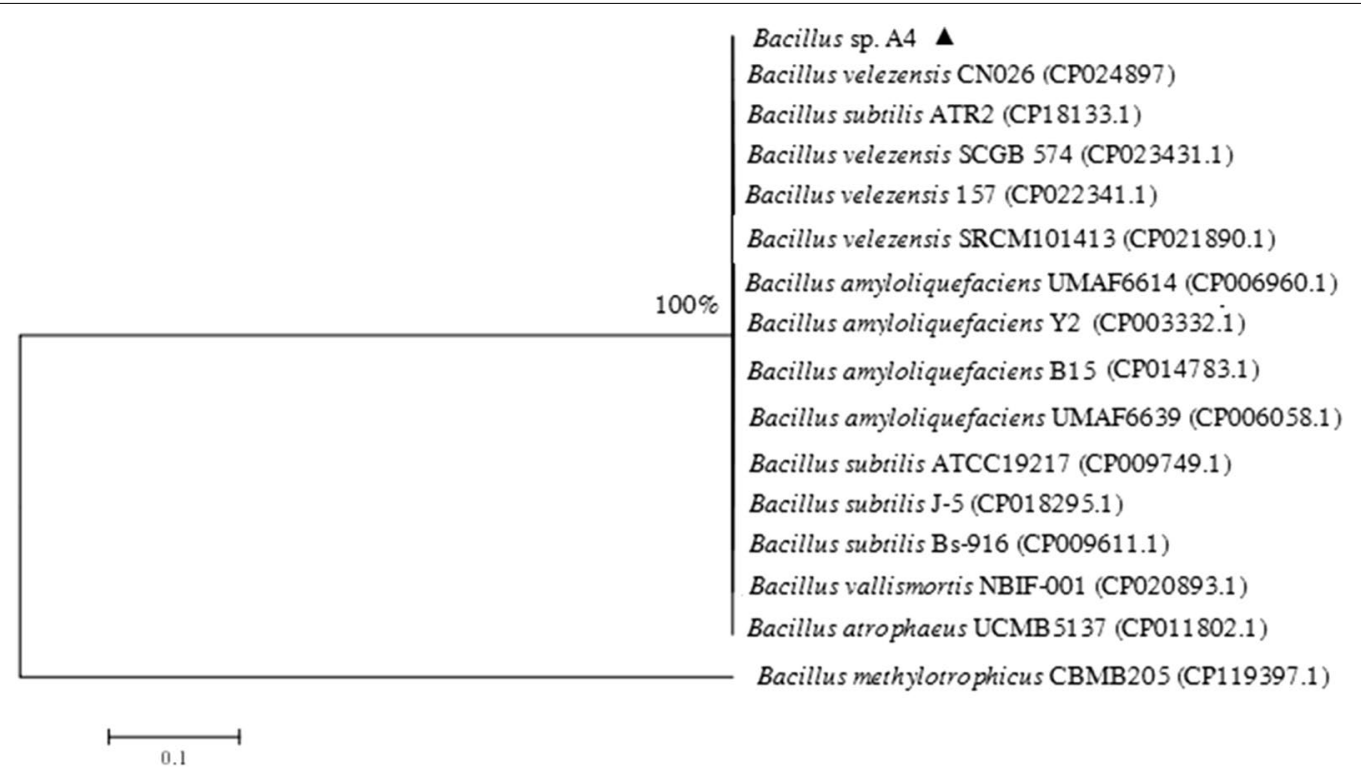

Fig. 2 Phylogenetic tree was constructed by neighbor-joining method using rpoB gene sequence obtained from different Bacillus strains in GenBank. The numbers at the branches indicate the confidence level calculated by bootstrap analysis (1000). The scale bar shows the evolutionary distance between species. The numbers in the brackets are the accession numbers of rpoB gene sequences from GenBank 


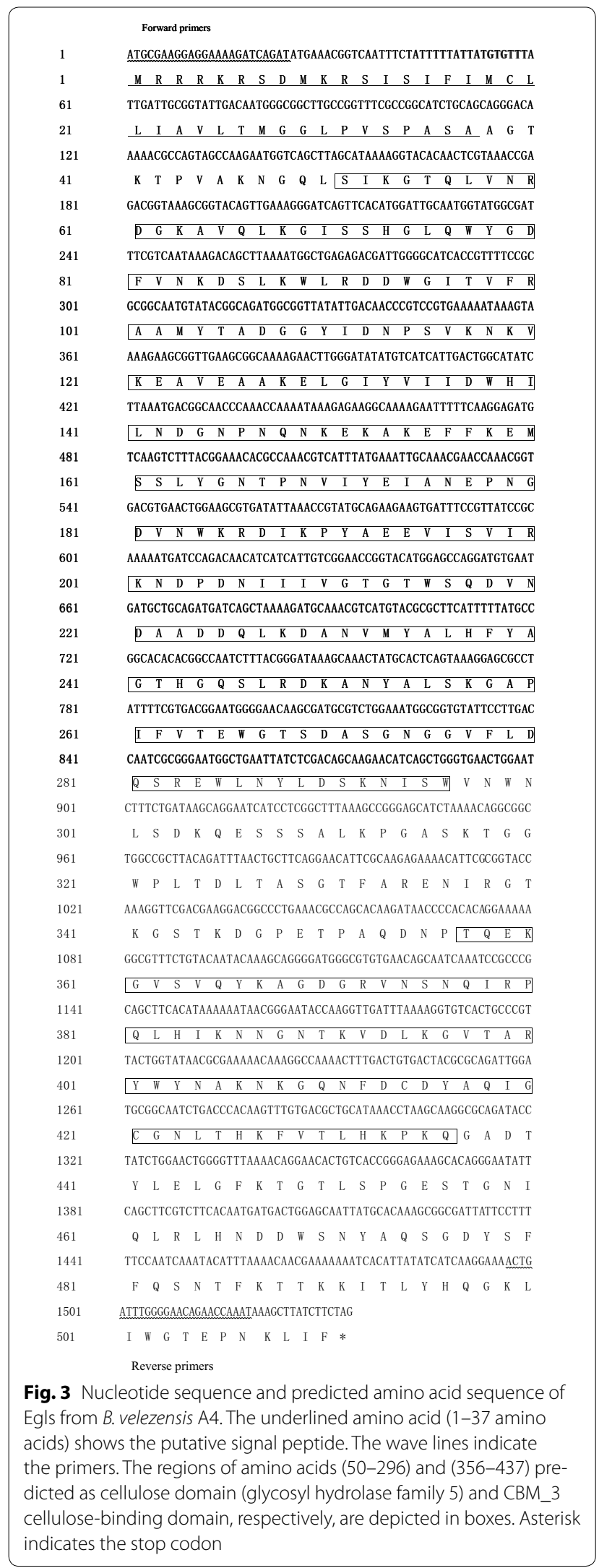

Due to the enzyme activity loss in NTA affinity column, the recombinant enzyme Egls was re-purified using PEG 4000, phosphate buffer, and $\mathrm{NaCl}$ aqueous two-phase system. Aqueous two-phase system is one of the most economical, high-efficient, easy-to-operate, and scale-up methods, which has been extensively used in bio-products purification, such as enzymes, proteins, nucleic acids, and amino acids (Ratanapongleka 2010). The factors, such as polymer molecular weight, $\mathrm{pH}$, temperature, biomolecule size, surface charge, also contribute to the partition behavior of biomolecules between the two phases (Ratanapongleka 2010). The Binodal curves were built to use as a guideline for the enzyme purification in ATPS (data not shown). Different concentrations of PEG4000, $\mathrm{K}_{2} \mathrm{HPO}_{4} / \mathrm{NaH}_{2} \mathrm{PO}_{4}$ buffer, $\mathrm{NaCl}$, and buffer $\mathrm{pH}$ were exploited to find the optimized condition for enzyme purification (Fig. 6). Results showed that $25 \%(\mathrm{w} / \mathrm{w})$ of PEG 4000, phosphate buffer $8.08 \%(\mathrm{w} / \mathrm{w})$ ( $\mathrm{pH}$ 6.0), and $\mathrm{NaCl}(5 \% \mathrm{w} / \mathrm{w})$ have the highest enzyme recover rate $(90.39 \%)$ and purification factor (12.05) (Table 1). These parameters were used to purify recombinant enzyme Egls from supernatant of the cells. The recombinant enzyme Egls was partitioned to the bottom phase (salt-rich phase) of this system. It has been found that some enzymes would tend to partition to the bottom phase when it was purified with two-phase system (Gu et al. 2012; Loc et al. 2013; Ramakrishnan et al. 2016). An increase of $\mathrm{pH}$ and $\mathrm{NaCl}$ concentration in the two-phase system leads to the decrease of recovery rate of Egls. The concentrations of polymers, buffers, and $\mathrm{NaCl}$ have great impact on the partition of protein in aqueous two-phase system (Asenjo and Andrews 2012).

\section{Biochemical properties of Egls The optimal $\mathrm{pH}$ and temperature}

The effects of $\mathrm{pH}$ and temperature on crude recombinant enzyme and purified enzyme activities were analyzed at different $\mathrm{pH}$ values (3.0-10.0) and temperatures (30$80{ }^{\circ} \mathrm{C}$ ) under standard conditions, respectively. Results showed that the enzyme has an optimal temperature at $55{ }^{\circ} \mathrm{C}$ and optimal $\mathrm{pH}$ at $5.0-6.0$ and (Fig. $7 \mathrm{a}, \mathrm{b}$ ). The enzyme characteristics were mainly determined by the structure of Egls. The optimal temperature and $\mathrm{pH}$ of endoglucanase were different from the different sources of Bacillus species (Table 2).

\section{The thermal and $\mathrm{pH}$ stability}

The thermal stability was assayed at different temperatures $\left(55-70{ }^{\circ} \mathrm{C}\right)$ for $1 \mathrm{~h}$. The results showed that the enzyme was inactivated after incubation at $70{ }^{\circ} \mathrm{C}$ for $30 \mathrm{~min}$ (Fig. 7c, d). The crude enzyme and the purified enzyme were stable at the $\mathrm{pH}$ range of 5.0-7.0. Egls was not thermostable at temperatures above $70{ }^{\circ} \mathrm{C}$ and it was 


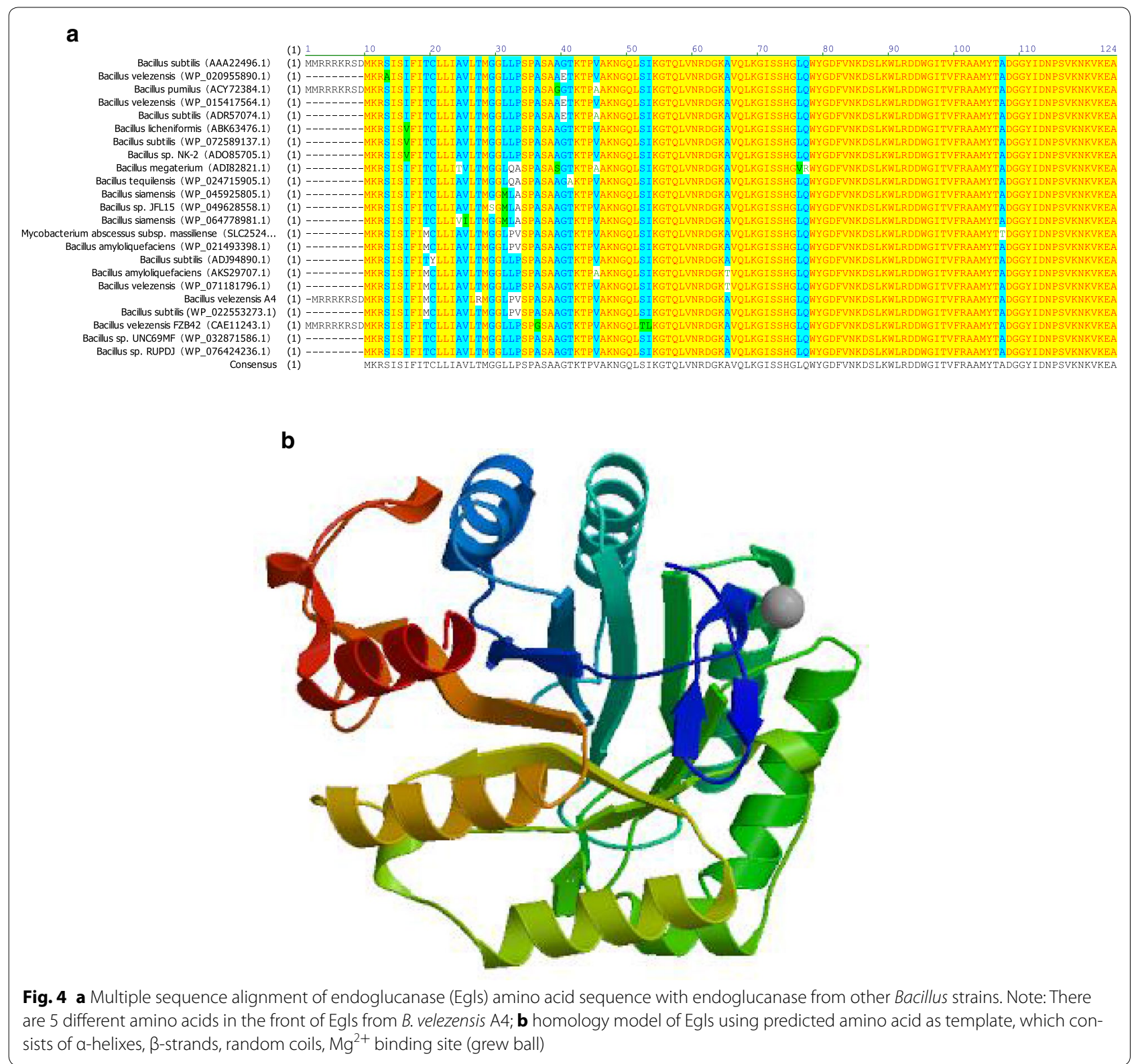

stable at nearly neutral $\mathrm{pH}$ environment. The enzyme properties are highly related to the structure of the enzyme. Some endoglucanases from Bacillus have higher thermostability, and others have a wider range of $\mathrm{pH}$ stability (Table 2).

\section{Effects of metal ions and chemicals on endoglucanase on enzyme activity}

The effects of different metal ions and chemicals on enzyme activity were analyzed (Table 3 ). Two $\mathrm{mM}$ of $\mathrm{Mg}^{2+}, \mathrm{Ca}^{2+}, \mathrm{K}^{+}$, and $\mathrm{Co}^{2+}$ slightly increased enzyme activity (5-10\%), while $\mathrm{Ni}^{2+}, \mathrm{Cu}^{2+}, \mathrm{Zn}^{2+}$, and $\mathrm{Mn}^{2+}$ almost have no effects on the enzyme activity. Ten $\mathrm{mM}$ of
$\mathrm{Mg}^{2+}, \mathrm{Ca}^{2+}, \mathrm{Mn}^{2+}$, and $\mathrm{Co}^{2+}$ increased the enzyme activity $(15-30 \%)$. Chemicals such as Triton-X 100, Tween$20(5 \% \mathrm{w} / \mathrm{v})$ increased the enzyme activity about 5 and $22 \%$, respectively. $5 \%(\mathrm{w} / \mathrm{v})$ EDTA slightly decreased the enzyme activity. However, PMSF strongly inhibited the enzyme activity.

\section{Kinetic parameters $K_{\mathrm{m}} / K_{\text {cat }}$}

The kinetic parameters $K_{\mathrm{m}} / K_{\text {cat }}$ were determined using various concentrations of $\mathrm{CMC}$ as substrate and analyzed with Lineweaver-Burk plot. The $K_{\mathrm{m}}, V_{\max }$, and $K_{\text {cat }}$ values of Egls were exhibited as $63.38 \mathrm{mg} / \mathrm{ml}, 55.6 \mathrm{mg} / \mathrm{min}$, and $3.93 \times 10^{3} / \mathrm{S}$, respectively. The value $K_{\mathrm{m}} / K_{\text {cat }}$ of Egls was 


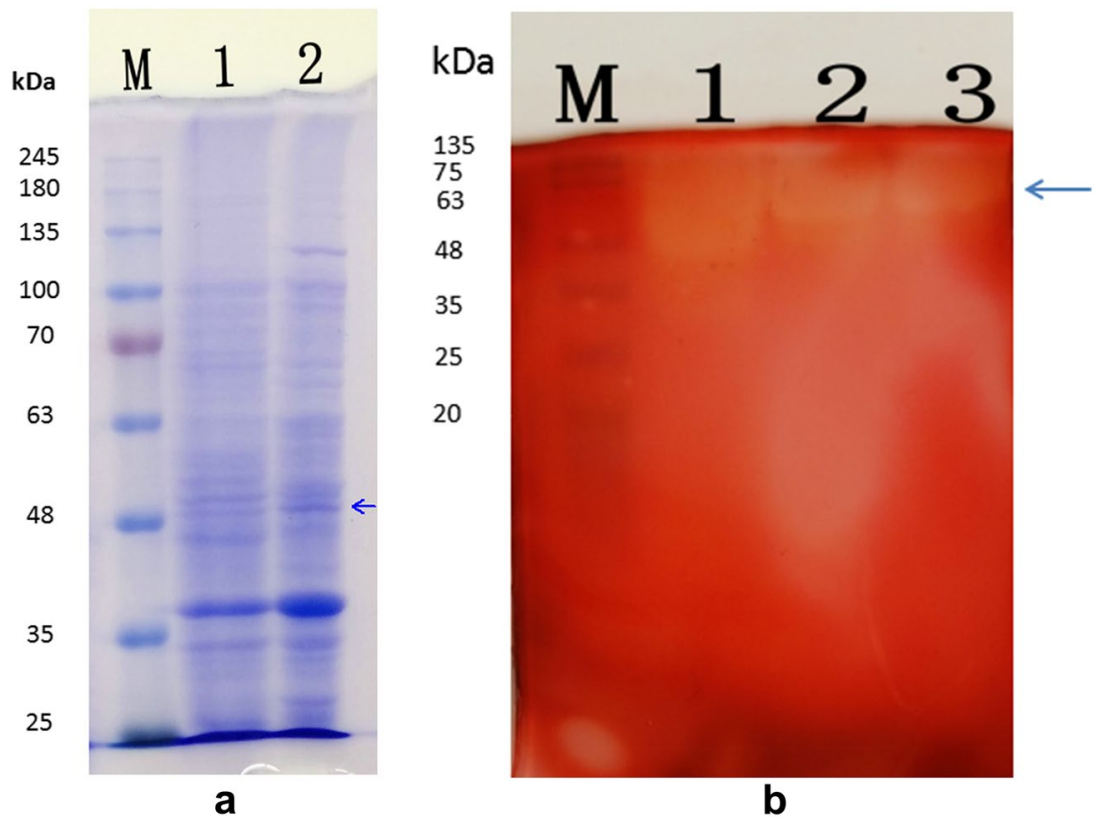

Fig. 5 a SDS-PAGE pattern of endoglucanase from pET21-egls/DE3 purified with ATPS. M Protein ladder; 1 control (without IPTG induction); 2 pET21-egls (induced with 1 mM IPTG); b zymogram analysis of crude enzyme and purified Egls. M Protein ladder; 1 crude enzyme (pET21-egls/DE3); 2 purified enzyme (pET 21-egls/DE3)

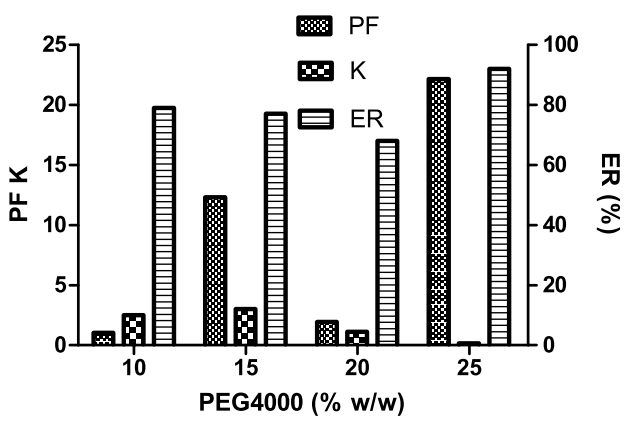

a

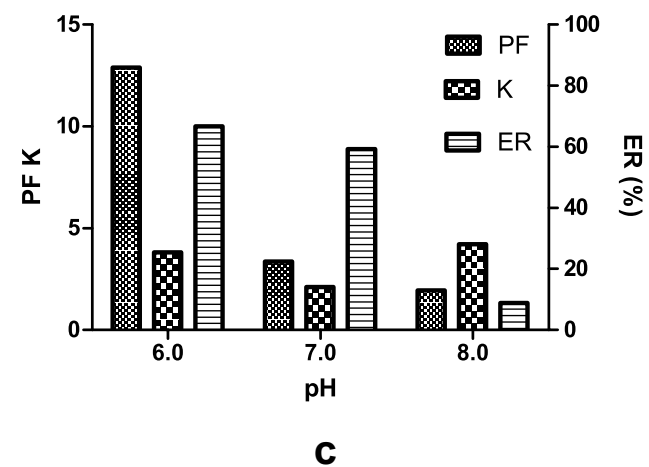

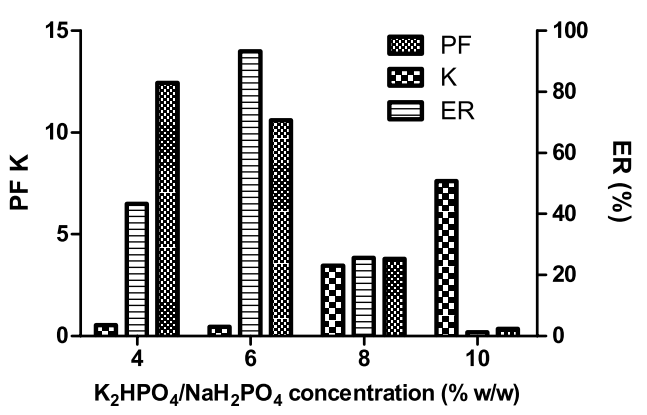

b

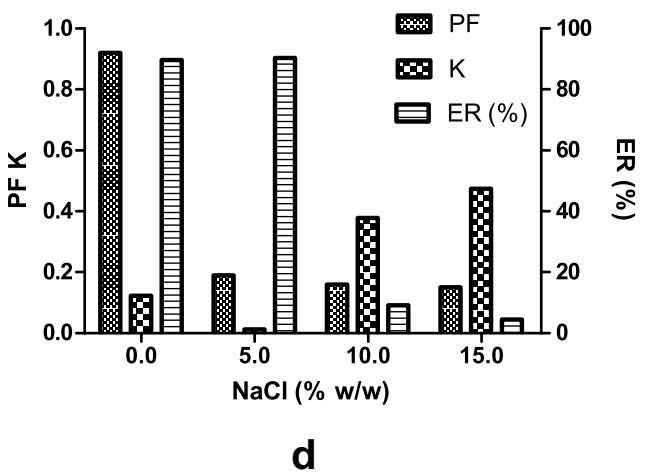

Fig. 6 Effect of PEG 4000, $\mathrm{NaCl}$ concentration, and pH on purification of endoglucanase from supernatants of pET21-egls/DE3 cells. PF purification factors, K partition coefficient, ER enzyme recovery. a PEG 4000 (10-25\%, w/w); b K2HPO4/NaH2PO4 (4-10\%, w/w); c pH (6.0-8.0); d NaCl (0-15\%, $\mathrm{W} / \mathrm{w})$ 
Table 1 Purification of recombinant enzyme Egls using PEG 4000-phosphate- $\mathrm{NaCl}$ system

\begin{tabular}{lccllll}
\hline Steps & Volume & Total protein $(\boldsymbol{\mu g} / \mathbf{m l})$ & Total CMCase $(\mathbf{U} / \mathbf{m l})$ & PF & CR & ER $(\%)$ \\
\hline Crude enzyme & 40 & $22,330.44$ & 1105.65 & 12.05 & 3.18 \\
Top phase & 140 & 2611.30 & ND & 1223.25 & & 90.39 \\
Bottom phase & 44 & 3235.91 & & & \\
\hline
\end{tabular}

ND not detected

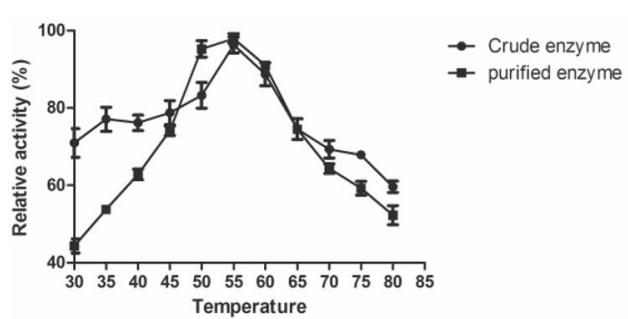

a

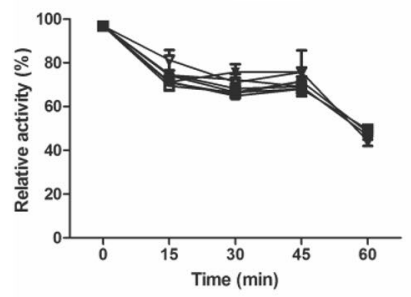

C

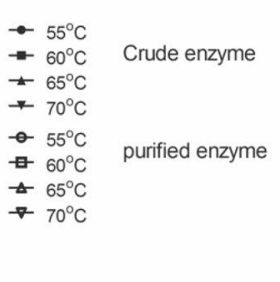

d

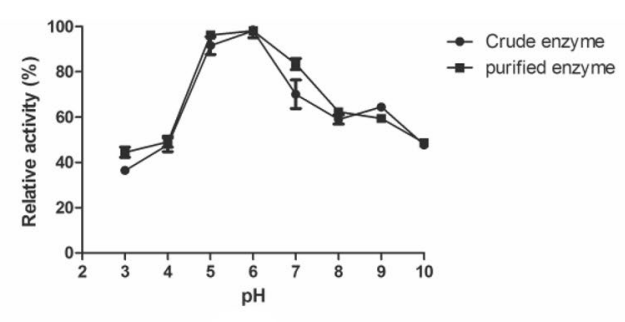

b

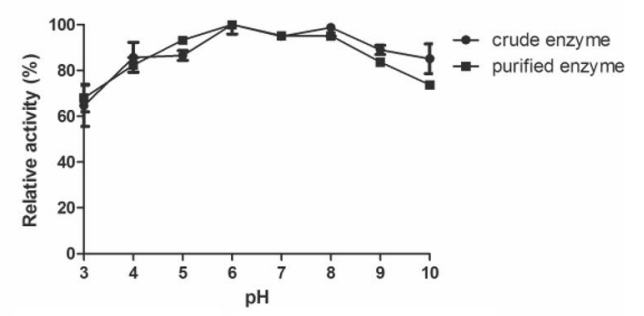

d

Fig. 7 Effect of pH and temperature on enzyme activities of Egls: a optimal temperature; $\mathbf{b}$ optimal pH; $\mathbf{c}$ pH stability; $\mathbf{d}$ thermal stability

Table 2 Endoglucanase properties from different Bacillus strains

\begin{tabular}{|c|c|c|c|c|c|c|}
\hline Bacillus strains & $\begin{array}{l}\text { Molecular weight } \\
\text { (MW) (kDa) }\end{array}$ & Optimal pH & $\begin{array}{l}\text { Optimal tempera- } \\
\text { ture }\left({ }^{\circ} \mathrm{C}\right)\end{array}$ & pH stability & Thermostability & Reference \\
\hline B. velezensis A4 & 55 & 6.0 & 55 & $5.0-8.0$ & $65^{\circ} \mathrm{C} 30 \mathrm{~min}$ & This study \\
\hline B. subtilis & 55 & & 50 & & $75^{\circ} \mathrm{C} 30 \mathrm{~min}$ & Li et al. (2008) \\
\hline B. amyloliquefaciens & 54 & 7.0 & 50 & & & Lee et al. (2008) \\
\hline B. licheniformis & 37 & 9.0 & 50 & 12 & $80^{\circ} \mathrm{C}$ & Annamalai et al. (2012) \\
\hline B. subtilis JS2004 & 63 & 9.0 & 50 & & & Zafar et al. (2014) \\
\hline
\end{tabular}

calculated as $1.74 \times 10^{-2} \mathrm{mg} / \mathrm{ml} \mathrm{S}$. The kinetic parameters $\left(K_{\mathrm{m}}, V_{\text {max }}\right.$, and $\left.K_{\text {cat }}\right)$ of an endoglucanase from Bacillus strain were found as $0.25 \mathrm{mg} / \mathrm{ml}, 20 \mu \mathrm{mol} / \mathrm{ml} / \mathrm{min}$, and $0.55 / \mathrm{S}$ respectively (Sadhu et al. 2013). The $K_{\mathrm{m}}$ of endoglucanase from the strain Hahella chejuensis KCTC 2396 was $1.8 \mathrm{mg} / \mathrm{ml}$ (Ghatge et al. 2014). The higher $K_{\mathrm{m}}$ value of our strain indicated that the enzyme Egls is less efficient in digesting CMC substrate than reported strains.

\section{Substrate specificity}

The substrates specificity was studied using different substrates (Table 4). Results showed that the purified enzyme Egls has higher CMC activity (75.61 $\pm 8.45 \mathrm{U} /$ $\mathrm{ml})$ and FPA activity $(69.22 \pm 8.52 \mathrm{U} / \mathrm{ml})$ than that of the crude enzyme, which indicated that the enzyme has endoglucanase activity. The purified enzyme has higher enzyme activity than crude enzyme, because the purified enzyme has more enzyme molecules than crude enzyme 
Table 3 Effect of metal irons and chemicals on purified recombinant enzyme Egls activities

\begin{tabular}{|c|c|c|c|c|c|}
\hline \multirow[t]{2}{*}{ Metal ions } & \multicolumn{2}{|c|}{ Relative activity (\%) } & \multirow[t]{2}{*}{ Chemicals } & \multicolumn{2}{|c|}{ Relative activity (\%) } \\
\hline & $2 \mathrm{MM}$ & $10 \mathrm{MM}$ & & $2 \%(w / v)$ & $5 \%(w / v)$ \\
\hline Control & $100.3 \pm 1.0$ & $100.3 \pm 1.0$ & Control & $100.3 \pm 1.0$ & $100.3 \pm 1.0$ \\
\hline $\mathrm{Ca}^{2+}$ & $105.2 \pm 2.3$ & $115.7 \pm 5.2^{\mathrm{a}}$ & Triton-X 100 & $105.0 \pm 4.4$ & $122.9 \pm 5.8^{\mathrm{a}}$ \\
\hline $\mathrm{K}^{+}$ & $105.5 \pm 1.8$ & $104.3 \pm 4.6$ & Twen-20 & $100.8 \pm 3.6$ & $105.2 \pm 2.5$ \\
\hline $\mathrm{Mg}^{2+}$ & $111.0 \pm 1.4^{\mathrm{a}}$ & $134.8 \pm 11.1^{\mathrm{a}}$ & EDTA & $99.6 \pm 0.6$ & $96.7 \pm 0.5$ \\
\hline $\mathrm{Mn}^{2+}$ & $101.7 \pm 1.7$ & $134.2 \pm 4.9^{\mathrm{a}}$ & PMSF & ND & ND \\
\hline $\mathrm{Ni}^{2+}$ & $98.8 \pm 3.1$ & $98.6 \pm 3.6$ & & & \\
\hline $\mathrm{Zn}^{2+}$ & $100.3 \pm 3.4$ & $122.0 \pm 1.8^{\mathrm{a}}$ & & & \\
\hline $\mathrm{Cu}^{2+}$ & $100.0 \pm 3.0$ & $103.5 \pm 4.8$ & & & \\
\hline $\mathrm{CO}^{2+}$ & $110.1 \pm 1.1^{\mathrm{a}}$ & $116.5 \pm 3.8^{\mathrm{a}}$ & & & \\
\hline
\end{tabular}

ND not detected

a Significant difference $(p<0.05)$

Table 4 Substrates specificity of crude and purified recombinant enzyme Egls

\begin{tabular}{lll}
\hline Substrates & Crude enzyme (U/ml) & Purified enzyme $(\mathbf{U} / \mathbf{m l})$ \\
\hline CMC & $22.06 \pm 4.61$ & $75.61 \pm 8.45^{*}$ \\
Filter & $40.84 \pm 6.38$ & $69.22 \pm 8.52^{*}$ \\
Avicel & $63.86 \pm 16.10$ & $68.84 \pm 24.81^{*}$ \\
pNPG & ND & ND
\end{tabular}

$N D$ not detected

* Significant difference $(p<0.05)$

in equal reaction volume and PEG 4000 existed in purified enzyme makes the enzyme more stable and increases enzyme activity. The purified enzyme Egls has an enzyme activity $(68.84 \pm 24.81 \mathrm{U} / \mathrm{ml})$ using Avicel as substrates, which was also higher than that of crude enzyme $(63.86 \pm 16.10 \mathrm{U} / \mathrm{ml})$. It indicated that the enzyme has both endoglucanase activity and exoglucanase activity. The enzyme cannot digest pNPG, which indicates that Egls has no $\beta$-glucanase activity. This result was in agreement with the findings that some cellulases from Bacillus showed both endoglucanase activity and exoglucanase activity (Sadhu et al. 2013; Ghatge et al. 2014; Wei et al. 2015). Egls is very useful for the pretreatment of lignocellulose of biomass to produce reducing sugar that is used in bio-products and bioenergy production.

\section{Conclusion}

We have cloned and expressed egls gene from $B$. velezensis A4 in E. coli BL21 (DE3). The recombinant enzyme was purified with PEG 4000, phosphate, and $\mathrm{NaCl}$ aqueous two-phase system. Although gene sequence was highly similar to other B. velezensis stain JS25R, this study is the first report of the recombinant expression, purification, and characterization of the enzyme. The recombinant enzyme is an endoglucanase, has an optimal temperature at $55^{\circ} \mathrm{C}$ and $\mathrm{pH}$ range of $5.0-6.0$, is stable at $\mathrm{pH}$ range of 5.0-7.0, and is actively supplemented with a series mental ions and can be used in biomass pretreatment to produce reducing sugars in bioenergy production. The study of the enzyme properties of the predicted cellulase genes is very important for the enzyme application in biomass degradation and bioenergy production.

\section{Authors' contributions}

$Y L$ conceived, designed, and performed the experiments. $\mathrm{HG}$ constructed the E. coli expression vector. YW performed a part of the experiments. WQ was involved in project planning, experimental designing, manuscript revisions, and editing. All authors read and approved the final manuscript.

\section{Author details}

${ }^{1}$ Department of Biology, Lakehead University, Thunder Bay, ON P7B 5E1, Canada. ${ }^{2}$ School of Life Science, Huzhou University, Huzhou 313000, Zhejiang, China. ${ }^{3}$ Zhejiang Provincial Key Laboratory of Aquatic Resource Conservation and Development, Huzhou University, Huzhou 313000, Zhejiang, China.

${ }^{4}$ State Key Laboratory of Plant Physiology and Biochemistry, College of Life Sciences, Zhejiang University, Hangzhou 310058, China. ${ }^{5}$ Co-innovation Center for Sustainable Forestry in Southern China, Jiangsu Province Key Laboratory of Soil and Water Conservation and Ecological Restoration, Nanjing Forestry University, Nanjing 210037, China.

\section{Acknowledgements}

We acknowledge the financial support of Natural Sciences and Engineering Research Council of Canada (NSERC Grant No. RGPIN-2017-05366) and BioFuelNet Canada (Project No. 67) to W.Q and China Scholarship Council (Grant No. 201608330437) to Y. L. We thank Dr. Frooq Khan and Prof. Z. Jiang for the help and providing some experimental materials and conditions in this research.

Competing interests

The authors declare that they have no competing interests.

Availability of data and materials

All data obtained or analyzed in this work are included in this article.

Consent for publication

Not applicable.

Ethics approval and consent to participate Not applicable. 


\section{Publisher's Note}

Springer Nature remains neutral with regard to jurisdictional claims in published maps and institutional affiliations.

Received: 18 March 2018 Accepted: 11 April 2018

Published online: 27 April 2018

\section{References}

Aljanabi S (1997) Universal and rapid salt-extraction of high quality genomic DNA for PCR-based techniques. Nucleic Acids Res 25:4692-4693. https:// doi.org/10.1093/nar/25.22.4692

Allison RD (2001) Kinetic assay methods. Curr Protoc Mol Biol Appendix 3

Annamalai N, Rajeswari MV, Elayaraja S et al (2012) Purification and characterization of thermostable alkaline cellulase from marine bacterium Bacillus licheniformis Au01 by utilizing cellulosic wastes. Waste Biomass Valoriz 3:305-310. https://doi.org/10.1007/s12649-012-9113-y

Asenjo JA, Andrews BA (2011) Aqueous two-phase systems for protein separation: a perspective. J Chromatogr A 1218:8826-8835. https://doi. org/10.1016/i.chroma.2011.06.051

Asenjo JA, Andrews BA (2012) Aqueous two-phase systems for protein separation: phase separation and applications. J Chromatogr A 1238:1-10. https://doi.org/10.1016/j.chroma.2012.03.049

Azevedo AM, Gomes AG, Rosa PAJ et al (2009) Partitioning of human antibodies in polyethylene glycol-sodium citrate aqueous two-phase systems. Sep Purif Technol 65:14-21. https://doi.org/10.1016/j.seppur.2007.12.010

Basu P (2013) Biomass gasification, pyrolysis and torrefaction: practical design and theory. Academic Press, Boston. https://doi.org/10.1016/ C2011-0-07564-6

Carson M, Johnson DH, McDonald H et al (2007) His-tag impact on structure. Acta Crystallogr Sect D: Biol Crystallogr 63:295-301. https://doi org/10.1107/S0907444906052024

Drancourt M, Raoult D (2002) rpoB Gene sequence-based identification of Staphylococcus species. J Clin Microbiol 40:1333-1338. https://doi. org/10.1128/JCM.40.4.1333

Dworkin M, Falkow S, Rosenberg E, Schleifer K-H, Stackebrandt E (eds) (2006) The prokaryotes. A handbook on the biology of bacteria. Springer, New York. https://doi.org/10.1007/0-387-30744-3

Fan B, Blom J, Klenk HP, Borriss R (2017) Bacillus amyloliquefaciens, Bacillus velezensis, and Bacillus siamensis form an "Operational group $B$. amyloliquefaciens" within the B. subtilis species complex. Front Microbiol 8:22. https://doi.org/10.3389/fmicb.2017.00022

Garvey M, Klose H, Fischer R et al (2013) Cellulases for biomass degradation: comparing recombinant cellulase expression platforms. Trends Biotechnol 31:581-593

Ghatge SS, Telke AA, Kang SH et al (2014) Characterization of modular bifunctional processive endoglucanase Cel5 from Hahella chejuensis KCTC 2396. Appl Microbiol Biotechnol 98:4421-4435. https://doi.org/10.1007/ s00253-013-5446-0

Ghose TK (1987) Measurement of cellulase activities. Pure Appl Chem 59:257-268. https://doi.org/10.1351/pac198759020257

Gu F, Gao J, Xiao J et al (2012) Efficient methods of purification of a-galactosidase from Aspergillus niger: aqueous two-phase system versus three-phase partitioning. Rom Biotechnol Lett 17:7853-7862

Guo H, Lin C, Wang S et al (2017) Characterization of a novel laccase-producing Bacillus sp. A4 and its application in Miscanthus degradation. BioResources 12:4776-4794

Hatti-kaul R (2001) Aqueous two-phase systems. Mol Biotechnol 19:697-713. https://doi.org/10.1385/MB:19:3:269

Ki JS, Zhang W, Qian PY (2009) Discovery of marine Bacillus species by $16 \mathrm{~S}$ rRNA and rpoB comparisons and their usefulness for species identification. J Microbiol Methods 77:48-57. https://doi.org/10.1016/j. mimet.2009.01.003

Lee YJ, Kim BK, Lee BH et al (2008) Purification and characterization of cellulase produced by Bacillus amyoliquefaciens DL-3 utilizing rice hull. Bioresour Technol 99:378-386. https://doi.org/10.1016/j.biortech.2006.12.013

Li W, Zhang WW, Yang MM, Chen YL (2008) Cloning of the thermostable cellulase gene from newly isolated Bacillus subtilis and its expression in
Escherichia coli. Mol Biotechnol 40:195-201. https://doi.org/10.1007/ s12033-008-9079-y

Lin C, Shen Z, Zhu T, Qin W (2015) Newly isolated Penicillium ramulosum N1 is excellent for producing protease-resistant acidophilic xylanase. J Mol Microbiol Biotechnol 25:320-326. https://doi.org/10.1159/000439170

Loc NH, Thi H, Lien T et al (2013) Purification of recombinant neutral protease (NPRC10) by partitioning in aqueous two-phase systems. Eur J Exp Biol 3:252-257

Masuko T, Minami A, Iwasaki N et al (2005) Carbohydrate analysis by a phenolsulfuric acid method in microplate format. Anal Biochem 339:69-72. https://doi.org/10.1016/j.ab.2004.12.001

Miller GL (1959) Use of dinitrosalicylic acid reagent for determination of reducing sugar. Anal Chem 31:426-428. https://doi.org/10.1021/ac60147a030

Mollet C, Drancourt M, Raoult D (1997) rpoB sequence analysis as a novel basis for bacterial identification. Mol Microbiol 26:1005-1011. https://doi. org/10.1046/j.1365-2958.1997.6382009.x

Pérez J, Muñoz-Dorado J, De La Rubia T, Martínez J (2002) Biodegradation and biological treatments of cellulose, hemicellulose and lignin: an overview. Int Microbiol 5:53-63

Porfiri MC, Picó G, Romanini D, Farruggia B (2011) Aspergillus oryzae alphaamylase partition in potassium phosphate-polyethylene glycol aqueous two-phase systems. Int J Biol Macromol 49:7-13. https://doi. org/10.1016/j.jijbiomac.2011.03.003

Rabinovich ML, Melnik MS, Bolobova AV (2002) Microbial cellulases (review). Appl Biochem Microbiol 38:305-321

Raja S, Murty VR, Thivaharan V et al (2012) Aqueous two phase systems for the recovery of biomolecules—a review. Sci Technol 1:7-16. https://doi org/10.5923/j.scit.20110101.02

Ramakrishnan V, Goveas LC, Suralikerimath N et al (2016) Extraction and purification of lipase from Enterococcus faecium MTCC5695 by PEG/ phosphate aqueous-two phase system (ATPS) and its biochemical characterization. Biocatal Agric Biotechnol 6:19-27. https://doi.org/10.1016/j. bcab.2016.02.005

Ratanapongleka K (2010) Recovery of biological products in aqueous two phase systems. Int J Chem Eng Appl 1:191-198. https://doi.org/10.7763/ IJCEA.2010.V1.33

Sadhu S, Maiti TK (2013) Cellulase production by bacteria: a review. Br Microbiol Res J 3:235-258. https://doi.org/10.9734/BMRJ/2013/2367

Sadhu S, Saha P, Sen SK et al (2013) Production, purification and characterization of a novel thermotolerant endoglucanase (CMCase) from Bacillus strain isolated from cow dung. Springerplus 2:1-10. https://doi. org/10.1186/2193-1801-2-10

Sharada R, Venkateswarlu G, Venkateshwar S, Rao MA (2013) Production of cellulase_-a review. ljpcbs 3:1070-1090

Sun Y, Cheng J (2002) Hydrolysis of lignocellulosic materials for ethanol production: a review q. Bioresour Technol 83:1-11. https://doi.org/10.1016/ S0960-8524(01)00212-7

Wei KSC, Teoh TC, Koshy P et al (2015) Cloning, expression and characterization of the endoglucanase gene from Bacillus subtilis UMC7 isolated from the gut of the indigenous termite Macrotermes malaccensis in Escherichia coli. Electron J Biotechnol 18:103-109. https://doi.org/10.1016/j. ejbt.2014.12.007

Yang TC, Kumaran J, Amartey S et al (2014) Biofuels and bioproducts produced through microbial conversion of biomass. Bioenergy Res Adv Appl. https://doi.org/10.1016/B978-0-444-59561-4.00005-X

Zafar M, Ahmed S, Khan MIM, Jamil A (2014) Recombinant expression and characterization of a novel endoglucanase from Bacillus subtilis in Escherichia coli. Mol Biol Rep 41:3295-3302. https://doi.org/10.1007/ s11033-014-3192-8

Zhang YHP, Hong J, Ye X (2009) Cellulase assay. Biofuels Methods Protoc Methods Mol Biol 581:213-231. https://doi.org/10.1007/978-1-60761-214-8 